\title{
LOW COST TECHNOLOGY FOR THE DEVELOPMENT OF COCONUT SMALLHOLDINGS
}

\author{
by
}

\author{
DR. D. V. LIYANAGE ${ }^{1}$
}

\begin{abstract}
SUMMARY
The management practices recommended to increase coconut production in smallholdings are largely based on a seed-fertilizeragrocide technology. The goal is to maximise production. HigI yielding varieties that need high inputs and management lavel, have been introduced. Application of chemical fertilizers pesticides and weedicides are advocated. The smallholders with limited funds at their disposal and faced with other constraints are unable to purchase the inputs. Thus an inappropriate technology is being passed on to them.

The smallholders need improved cultivars that produce more nuts not necessarily very high yields - and low cost management practices. Cost of application of chemical fertilizers and cultural practices constitute $64 \%$ and $13 \%$ respectively of the total expenditure on the maintenance of coconut holdings. Any technology developed to reduce expenditure on these two items would be of considerable benefit to the smallholders. A feasible approach to achieve this goal is bio-farming.

Bio-farming is building up fertility of the soil by incorporating organic material with minimal use of inorganics. Integrating animal husbandry with coconut cultivation and integrated pest control measures are important aspects of this system. The fertility of the soil is maintained for successive generations to grow crops successfully. The cost of inputs is reduced considerably as micro-organisms and earth worms flourish under these conditions and convert waste into minerals. The eco-system remains stable. Bio-farming is a low cost technology suitable for the coconut smallholders to increase production and productivity. More research is necessary on different aspects of building up humus in the soil.
\end{abstract}

\section{INTRODUCTION}

The smallholders are generally rational and efficient operators, who work under difficult personal circumstances, different priorities and values compared to the large estate owners. Some of the factors that determine their decesions are: limited availability of funds, risks that arise from time to time due to crop failures, fluctuating prices and inability to provide the necessary inputs to increase production (Fowler and Teskey, 1985). Any advice given by the extension officers to improve crop production should include factors, to ameliorate these constraints.

In the recent past, a number of countries have carried out development programmes. to increase coconut production, yet it has remained stagnant or declined. This is largely due to inadequacies with regard to policy matters, research objectives and extension outlook: an inappropriate technology has been imposed on the farmers disregarding the problems faced by them.

\footnotetext{
${ }^{1}$ Chairman, Coconut Research Board, Lunuwila, Sri Lanka.
} 


\section{CURRENT MANAGEMENT PRACTICES}

The current practices recommended for the coconut smallholders to improve production encompass; to a large extent a seedfertilizer-agrocide technology. Planting material consists; of hybrids derived by crossing Dwarf $x$ Tall coconut varieties. They are earlybearing and could produce 3 to 4 tons of copra ha/yr. provided the agroclimatic conditions are suitable for coconut cultivation and management levels are satisfactory. They are, not so hardy as the Tall variety that is commonly grown and cannot withstand droughts longer than 6 continuous weeks, subject to soil conditions. Application of high doses of chemical NPK fertilizer is recommended. Weedicides and pesticides are applied to control weeds and pests.

The farmer has to purchase all these inputs from outside sources which is difficult as his funds are restricted. The risks due to crop losses and fluctuating prices-sometimes below the cost of production-discourage him, to apply the inputs. NPK fertilizer has to be applied year after year, otherwise, there is a sudden drop in production. Pesticides are not selective, both beneficial and harmful insects are destroyed with the spray, disrupting the eco-system.

Considering the constraints faced by the farmers, a technology of this type is inappropriate for the smallholders. They need improved cultivars that produce more nuts that are marketable - not necessarily very high yields - and low cost management practices. Unfortunately, the main thrust of the researchers has been to maximize production from the coconut holdings through a system of chemical farming which may be satisfactory for the estates, but not for the smallholdings. According to Jah (1985) coconut hybrids were issued to smallholders in Malaysia in the early seventies hoping to give a boost to their income from the high-yields expected from the hybrids. Unfortunately, "the farmers were finding . . . the fruits not readily marketable: retail niarkets found it not popular among housewives, fruits too small for home or shop-keepers' scrapers, too oily and lacking in the right flavour.....It seems reasonable to accept the opinion that we have made a mistake in technology transfer".

The broad parameters that contribute to the cost of production in coconut smallholdings in Sri Lanka that receive NPK inorganic fertilizer and satisfactory management practices are given in Table 1 (CDA, 1984). The expenditure on fertilizer and cultural practices amount to $64 \%$ and $13 \%$ respectively of the total expenditure. Therefore, any technology developed to reduce expenditure on these two items will facilitate small farmers to increase coconut production and their income. A feasible approach to achieve this goal is to introduce bio-farming.

Table 1.

Expenditure on maintenance of one hectare of smallholder coconut land in Sri Lanka

\begin{tabular}{|l|c|}
\hline \multicolumn{1}{|c|}{ Item } & Expressed a \% of total expenditure \\
\hline Fertilizer and application & 60 \\
Cultural practices & 14 \\
Plant protection & 9 \\
Harvesting & 13 \\
Miscellaneous & 4 \\
\hline
\end{tabular}

Note: This table does not include interest on working capital, recovery on investment and overhead charges. 


\section{Bio-farming}

Frissel (1978) has pointed out that fertilizers, particularly those containing nitrogen, require fossil energy in their manufacture which is becoming increasingly expensive and further a diminishing resource. The economically workable deposits of the raw materials used to produce phosphorus and potassium fertilizers do not have an infinite life. These considerations amongst others, emphasize the necessity for the development of systems for- the movement of nutrients for the growth of plants and animals from soil - plant - animal - soil again. He describes this system as nutrient cycles: bio-farming in other words.

Bio-farming is essentially building up fertility of the soil using organic material that promotes active growth of the earth worms and micro-organisms in the soil with minimal use of chemical fertilizer and agrocides.

An efficient way to maintain the organic matter and increase fertility in the soil is by planting leguminous creeping covers and tree crops and incorporating the biomass into the soil. But that is not possible in smallholdings where priority may be food production for the family. The cover crops recommended now complete the life cycle in about six months - too long a period for the land to be left under non-edible crops. Nevertheless, burying coconut husks, aerial portions of root and tuber crops and other refuse including kitchen ash available on the farm could add organic matter to the soil. Quick growing leguminous, trees like gliricidia and leucaena species should be grown along the fence and inside the block where-ever possible. They have to be regularly lopped and the leaves and branches buried in the soil.

The researchers should develop quick growing leguminous cover crops that grow under the shade of coconut palms and produce large quantities of nitrogen in the root nodules and vegetative material within about three months, preferably with edible pods and leaves. Most of the cover crops available today, eg. Mucuna utilis, Calpagonium spp. etc. take about six months to complete the life cycle and could produce about $200 \mathrm{~kg}$ of nitrogen and 10 tons of vegetative material per ha/yr. It may be possible to breed strains of some of these varieties to complete the life cycle in a shorter period without reducing the production of vegetative material. The farmers could afford to leave the land under cover crops for four months every two years to enrich the soil.

Integrating animal husbandry with coconut cultivation is appropriate for the smallholder: raising cattle, goats and chicken without over-stocking. Improved pasture and fodder for the cattle and goats have to be produced in the smallholding. The animal dung when applied to the palms provide a major portion of the nutrients, but not a complete mixture. Nair etal (1979) have assessed the productivity from one hectare of coconut land with 4 milk cows fed on improved pasture and legUmes grown on the land. The income derived by the farmer then (in 1976) was sufficient to support a medium sized family on average living conditions. Cow dung and barn waste were used to manure the palms. They have described a number of systems that could be practised based on mixed farming, growing of leguminous plants insitu and green manuring. The type to suit a particular group of farmers has to be selected on a basis of the environment and their socio-economic conditions.

With this system of farming, the farmer could provide most of the inputs necessary to increase coconut production from the farm itself at a low cost and also receive an additional income by selling the produce from the animals.

Application of animal dung in sufficient quantities provides adequate $\mathrm{N}$ to the coconut palms, but has to be supplemented with $\mathrm{P}$ and $\mathrm{K}$ to produce a balanced mixture. The palms then grow healthily with dark green leaves without showing any deficiency symptoms. Since transport of animal manure is cumber some and expensive, cattle, goats and chicken should be raised on coconut land. The composition of three types of farm yard manure and the quantities required per bearing 
palm are given in Tables 2 and 3 (Coconut Research Institute, Sri Lanka, 1967). The figures given may vary from place to place depending on the management practices, etc.

Since with bio-farming, application of $\mathrm{N}$ - a nutrient that is increasing in price yearly and a diminishing resource - and $\mathrm{P}$ could be eliminated altogether under the conditions as in Sri Lanka; there is a saving of $45 \%$ compared to the use of inorganics only. Further with zero tillage, expenditure on cultural practices could be reduced by about $50 \%$. In this way the total cost of production of nuts is reduced by about $34 \%$.

However there are some problems. The pTesent rate of stocking cattle with improved pasture is about 5 heads/ha. They could provide dung to manure only 68 palms $/ \mathrm{yr}$ on a basis of the recommenclations given above, whereas the normal stand of coconut palms is 155 per ha. Considering the fact that growing leguminous cover and tree crops and burying the biomas in the soil provide additional $\mathrm{N}, \mathrm{P}$ and $\mathrm{K}$, the total quantity of dung, $\mathrm{P}$ and $\mathrm{K}$ apphed to the palms could be further reduced. Knowledge on these aspects of manuring is meagre and research on them is an urgent necessity.

Table 2. Chemical Compossition

\begin{tabular}{|l|c|c|c|c|}
\hline \multirow{2}{*}{ Material } & Moisture & $\mathbf{N}$ & \multirow{2}{*}{$\mathbf{P}_{\mathbf{2}} \mathbf{O}_{\mathbf{5}}$} & \multirow{2}{*}{$\mathbf{K}_{\mathbf{2}} \mathbf{O}$} \\
\cline { 2 - 3 } & \multicolumn{2}{|c|}{ Percent } & 0.2 to 0.4 & 0.3 to 0.6 \\
Cattel dung (fresh) & 45 to 55 & 0.4 to 0.8 & 0.4 to 0.7 & 0.6 to 1.1 \\
Cattel dung (dry) & 8 to 12 & 0.7 to 1.5 & Traces & 1.5 \\
Cattel urine & - & 1.1 & 0.4 to 0.7 & 1.0 to 1.5 \\
Goat dung & 10 to 15 & 2 to 3 & 0.8 to 1.0 & 1.0 to 1.5 \\
Poultry dropping & 30 to 60 & 1 to 1.5 & & \\
\hline
\end{tabular}

Table 3. Quantity of organic manure required per palm per year in Sri Lanka

\begin{tabular}{|l|l|l|}
\hline & \multicolumn{1}{|c|}{ Latteric gravel \& sandy soils } & \multicolumn{1}{c|}{ Loamy soils } \\
\hline Cattel manure (dry) & $35 \mathrm{~kg}+1 \mathrm{~kg}$ muriate of potash & $30 \mathrm{~kg}+1 / 2 \mathrm{~kg}$ muriate of potash \\
Goat manure & $18 \mathrm{~kg}+-\mathrm{do}-$ & $15 \mathrm{~kg}+-\mathrm{do}-$ \\
Poultry manure & $25 \mathrm{~kg}+-\mathrm{do}-$ & $20 \mathrm{~kg}+-\mathrm{do}-$ \\
\hline
\end{tabular}

\section{The advantages of bio-farming}

Soil made rich with micro-organisms and earth worms

nutrients are gradually released so that yields do not fall suddenly;

soils maintained in good physical condition improving aeration, structure and their moisture holding capacity;

- $\quad$ NPK minerals are added that increase vigour of crops and their resistance to pests and diseases and zero tillage necessary. 
Bio-farming creates a congenial environment for the earth worms to live in the soil. They play a vital role in improving the soil (Sabaratnam, 1984).

Organic waste is turned into soil nutrients by their constant burrowing, mixing and digesting;

keeps the soil loose and rich giving it a better capacity to retain air and water;

- neutralize the exoessively acidic or alkaline soils,

- $\quad$ transport minerals and sub-soil compounds from the depth of the soil to the surface;

- $\quad$ earthworm excreta contains twice the amount of $\mathrm{P}$ and eleven times $\mathrm{K}$ than present in the surrounding soil and

promote bacterial growth, especially actinomycetes.

Earth worms that convert organic waste into compost are produced by certain UK companies on contract. About 50,000 tiger earth worms (Eisenia foetida) could deodorise one cubic metre of waste in 24 hours. After that they accelerate the composting process causing chemical changes and producing odour free compost that is rich in humus. Once the composting is over, the earth worms are extracted from the compost and re-cycled or used to provide high protein animal feed.

Thus, if the small coconut growers could be encouraged to develop a system of bio-farming, cost on the application of artificial fertilizer could be reduced by about two-fifths, production increased, soil fertility maintained and cost of production of nuts reduced.

\section{Integrated Pest Control}

Integrated pest control is an aspect of biological farming. The tendency today to control an out-break of a pest is by spraying insecticides. These are generally not selective, both beneficial and destructive insects are destroyed in the prooess of spraying, disrupting the eco-system. These disadvantages could be overcome by adapting an integrated programme of pest control: minimal use of insecticides combined with the introduction of selected parasites that attack the pest. A good example is the control of the Philippine coconut beetle (Promecotheca cumingi) in Sri Lanka. The pest inadvertently introduced in October 1970 was controlled with in two years (Fernando, 1972). Integrated pest control methods are less expensive than chemical control and the balance of the eco-system is maintained.

\section{Conclusions}

If the small coconut growers could be encouraged to follow a system of bio-farming the costs on application of fertilizer and cultural practices (Table 1) could be reduced by ahput onethird.

The fertility of the soil is maintained for successive generations to grow crops successfully. Cost of inputs is reduced considerably by encouraging micro-organisms and earth worms to flourish in the soil. In fact, the earth worms could be the most beneficial animals in agriculture.

Bio-farming is a low cost technology suitable for the development of coconut smallholdings to increase production and productivity. 


\section{References}

C D A, 1984. Cost of maintenance of one acre of land (Unpublished).

Coconut Research Institute, Sri Lanka, 1967. Leaflet No. 9

Fernando, A S 1972. Concluding report on control of Promecotheca cumingi. Ceylon Coconut Quarterly, Vol. 23-24

Fowler, M H and Teskey, G 1985. The role of the small holder farming in rural development. APCC Quarterly Supplement 01/85.

Frissel, M J 1978. Cycling of mineral nutrients in agricultural ecosystems. Elsevier Scientific Publishing Company, Amsterdam.

Jah, N.H. 1985. Guide hnes for extension workers. Paper presented at Workshop on Organisation, Programmes and Training of officials and small coconut farmer's leaders in coconut extension, ESCAP, Bangkok, August 1985.

Nair, P K R 1979. Intensive multicropping with coconuts in India. Verlog Paul Parey, Berlin.

Sabaratnam, T. 1984. Ceylon Daily News. 26.6.84. 